\title{
陆架斜坡海域水平阵波束形成阵增益仿真分析
}

\author{
谢否, 孙超* \\ 西北工业大学航海学院, 西安 710072 \\ *联系人, E-mail: csun@nwpu.edu.cn \\ 收稿日期: 2016-03-01; 接受日期: 2016-04-29; 网络出版日期: 2016-08-11 \\ 国家自然科学基金资助项目(编号: 11534009, 51479169)
}

\begin{abstract}
摘要陆架斜坡海域海洋环境复杂多变, 水下声基阵在该海域实际应用时, 阵元接收信号的幅度和相位会发 生畸变, 阵元间信号相关性减弱, 会带来波束形成器阵增益的严重下降, 进而导致声呐探测性能的损失. 目前陆 架斜坡海域不同波束形成器阵增益的研究较少见, 本文在各向同性噪声场假设条件下, 针对陆架斜坡海域上坡 波导环境中水平阵的常规波束形成器(CBF)、最小方差无失真响应波束形成器(MVDR-BF) 和特征值波束形成 器(EBF)的阵增益进行仿真研究. 结果表明: (1) CBF和MVDR-BF的阵增益均与声场水平纵向相关性有关, 当水 平阵的阵元个数超过一定值时, 两种波束形成器的阵增益均不再随着阵元个数的增加而增大; (2) EBF的阵增益 由信号协方差矩阵最大特征值与其所有特征值之和的比值决定; (3) 当接收数据信噪比为 $-10 \mathrm{~dB}$ 时, MVDR-BF 的阵增益高于 $\mathrm{CBF}$, 但两者均小于 $\mathrm{EBF}$ 的阵增益.
\end{abstract}

关键词陆架斜坡, 阵增益, 波束形成, 声场水平纵向相关性

PACS: $43.30 .+\mathrm{m}, 43.60 .+\mathrm{d}, 43.60 . \mathrm{Fg}$

水下声基阵在陆架斜坡海域使用时, 受声速剖 面、海底地形、海流、內波等因素的影响, 阵元接收 信号的幅度和相位畸变较为严重, 致使阵元间接收信 号的相关性减弱, 最终导致声呐探测性能下降. 阵增 益定义为基阵输出端的信噪比与单个阵元输出信噪 比的比值 ${ }^{[1]}$, 是衡量传感器阵列波束形成器性能的重 要指标之一. 因此, 对该类海域声基阵波束形成阵增 益的研究具有重要意义.

1973年 $\operatorname{Cox}^{[2]}$ 提出了线列阵接收信号相关性随阵 元间距变化的指数衰减模型, 指出在不相关噪声环境 中, 对于无限长的线列阵, 常规波束形成处理器的阵增
益不超过 $(1+\rho) /(1-\rho)$ ( $\rho$ 为相邻两阵元间接收信号的相 关系数), 并给出了一种简单的分子阵方法, 以便得到 较高的基阵处理增益. Green ${ }^{[3]}$ 考虑了线性衰减的信号 空间相关模型, 对于给定阵列长度的直线阵, 给出了 最佳的子阵划分个数, 以提高阵增益. 但 $\mathrm{Cox}$ 和 Green 的研究均是在平面波模型下开展的. Hamson ${ }^{[4]}$ 基于简 正波模型, 详细研究了浅海垂直阵阵增益, 指出影响 阵增益的主要因素有接收阵的距离、海底底质和地 形. Morgan ${ }^{[5]}$ 详细比较了匹配场波束形成器、理想波 束形成器、带宽波束形成器、特征值波束形成器、 分子阵波束形成器等五种波束形成器的阵增益. Yoo

引用格式: 谢否, 孙超. 陆架斜坡海域水平阵波束形成阵增益仿真分析. 中国科学: 物理学力学天文学, 2016, 46: 094308

Xie L, Sun C. Array gain of a horizontal uniform linear array in the continental shelf slope (in Chinese). Sci Sin-Phys Mech Astron, 2016, 46: 094308, doi: 10.1360/SSPMA2016-00123 
和Yang ${ }^{[6]}$ 在夏季浅海环境下, 分析了常规波束形成方 法和匹配场处理方法的信号增益、噪声增益和阵增 益随距离变化的曲线, 指出由于受浅海环境信号多途 效应的影响, 常规波束形成信号增益损失很大, 匹配 场处理虽然能够获得理论上的信号增益, 但其对定向 噪声的抑制能力较差. 刘清宇等人 ${ }^{[7]}$ 对水平长线阵在 浅海多途信道中的指向性进行了分析, 比较了平面波 假设条件和简正波声场模型下的基阵指向性. 宋俊 ${ }^{[8]}$ 在其博士论文中详细分析了浅海信道中水平阵的阵 增益. 于瀚 ${ }^{[9]}$ 研究了浅海声场的时空相关特性及其衰 减规律, 并分析了声信号相关衰减对基阵增益影响. 这些工作均是在浅海环境下, 利用水平不变条件下简 正波模型进行的研究, 而在陆架斜坡海域, 波导环境 与距离有关, 水平不变简正波模型不适用.

RAM模型 ${ }^{[10]}$ 可用于波导环境随距离变化海域的 声场计算. 本文基于RAM模型, 利用文献[11]中给出 的声场相关系数公式, 计算陆架斜坡海域的声场相关 性, 并在陆架斜坡海域上坡波导环境中, 对均匀水平 直线阵 CBF、MVDR-BF和EBF波束形成器的阵增益 进行仿真研究.

\section{1 三种波束形成器的阵增益}

设声源辐射信号为窄带信号, $N$ 元均匀水平线列 阵(ULA)的第 $i$ 个阵元接收信号为 $s_{i}$, 接收噪声为 $n_{i}$, 则 阵元接收数据可表示为

$x_{i}=s_{i}+n_{i}$.

阵增益(Array Gain, AG) 定义为基阵输出信噪比 与单个阵元信噪比之比:

$A G=\frac{S N R_{\text {array }}}{S N R_{\text {hyp }}}$,

式中, $S N R_{\text {array }}$ 表示基阵输出信噪比, $S N R_{\mathrm{hyp}}$ 表示单个阵 元输出信噪比. 则不同的波束形成算法的阵增益可表 示为

$A G=\frac{\left|\sum_{i=1}^{N} w_{i} s_{i}\right|^{2}}{\left|\sum_{i=1}^{N} w_{i} n_{i}\right|^{2}} / \frac{\sum_{i=1}^{N}\left|s_{i}\right|^{2}}{\sum_{i=1}^{N}\left|n_{i}\right|^{2}}$,

式中, $w_{i}$ 表示第 $i$ 个阵元的加权系数. 三种波束形成器 分别对应 3 种不同的加权方式.

\section{1 常规波束形成器}

常规波束形成(Conventional Beamformer, $\mathrm{CBF}$ ) 是 通过设定合适的加权系数, 对各阵元接收数据进行延 迟求和的处理过程. 在接收信号为窄带信号的假设条 件下, 常规波束形成器加权向量 $\boldsymbol{w}$ 的第 $i$ 元素为

$w_{i}=\exp [-\mathrm{j} \omega(i-1) \Delta t]$,

式中, $\Delta t=d \cos \theta / c, c$ 为海水中声速, $d$ 为均匀线列阵阵 元间距, $\omega$ 为信号角频率, $\theta$ 为信号到达方向, $j$ 为虚数 单位. 计算常规波束形成器的阵增益时, $\theta$ 等于波达方 向角. 则常规波束形成器的第 $i$ 个加权系数为

$w_{\mathrm{CBF}, i}=\exp [-\mathrm{j} \omega(i-1) d \cos \theta / c]$.

\subsection{MVDR波束形成器}

最小方差无失真响应波束形成器(Minimum Variance Distortionless Response Beamformer, MVDR-BF) 是 $\mathrm{Capon}^{[12]}$ 于 1969 年提出的. 其目的在于约束基阵的加 权向量, 使在期望方向上形成一个单位幅度的波束, 同时使基阵的均方输出达到最小, 从而减小基阵对非 期望方向上激励的响应. MVDR-BF的目标函数可表 示为

$\min \boldsymbol{w}^{\mathrm{H}} \boldsymbol{R} \boldsymbol{w}$, s.t. $\boldsymbol{w}^{\mathrm{H}} \boldsymbol{a}(\theta)=1$,

式中, $\boldsymbol{R}$ 为接收数据的协方差矩阵, $\boldsymbol{a}(\theta)$ 为基阵的阵列 流形向量. 使用标准Lagrange乘子法求解式(6)中的最 优化问题, 可得到MVDR加权向量为

$\boldsymbol{w}_{\mathrm{MVDR}-\mathrm{BF}}=\frac{\boldsymbol{R}^{-1} \boldsymbol{a}(\theta)}{\boldsymbol{a}^{\mathrm{H}}(\theta) \boldsymbol{R}^{-1} \boldsymbol{a}(\theta)}$,

\section{3 特征值波束形成器}

由以上分析可以看出, CBF和MVDR-BF的性能均 依赖于基阵的阵列流形, 而在实际海洋环境中阵列流 形估计难度大, 且很难估计准确. 特征值波束形成器 (Eigenvalue Beamformer, EBF) 与以上两种波束形成器 不同, 是通过对接收信号协方差矩阵进行特征分解, 然 后利用信号特征值对应的特征向量进行加权. 如果接 收信号的协方差矩阵表示为 $\boldsymbol{R}_{\mathrm{s}}$, 对其进行特征分解得

$\boldsymbol{R}_{\mathrm{s}}=\boldsymbol{E} \boldsymbol{\Lambda} \boldsymbol{E}^{\mathrm{H}}$, 
式中, $\boldsymbol{E}$ 和 $\boldsymbol{\Lambda}$ 分别为 $\boldsymbol{R}_{\mathrm{s}}$ 的特征向量矩阵和特征值矩阵. 选取 $\Lambda$ 中最大特征值对应的特征向量作为特征值波束 形成器的加权向量 $\boldsymbol{w}_{\mathrm{EBF}}$, 即可得到特征值波束形成器.

\section{2 仿真实验}

本文利用RAM声场计算模型, 对陆架斜坡海域上 坡声传播时的声场相关性、接收信号协方差矩阵特 征值, 以及波束形成器的阵增益进行仿真研究.

\section{1 陆架斜坡海域上坡声传播}

仿真中考虑的海洋环境跨越深海、斜坡和浅海三 种类型海域.其中深海海域水深为 $5000 \mathrm{~m}$, 自声源位置 处延伸 $2 \mathrm{~km}$ 的距离到达斜坡海域; 斜坡海域跨越 $78 \mathrm{~km}$ 的距离, 斜坡倾斜度为 $3.5^{\circ}$, 水深由 $5000 \mathrm{~m}$ 到 $229 \mathrm{~m}$ 变 化; 浅海海域水深为 $229 \mathrm{~m}$, 延伸 $20 \mathrm{~km}$ 的距离. 海底的 声吸收系数均为 $0.5 \mathrm{~dB} / \lambda$. 声源位于 $550 \mathrm{~m}$ 深度处, 发射 中心频率为 $190 \mathrm{~Hz}$ 、带宽为 $10 \mathrm{~Hz}$ 的窄带信号. 由 101 个阵元组成均匀水平线列阵, 阵元间距为 $4 \mathrm{~m}$. 图 1 给出 了仿真环境及参数示意图. 在仿真中考虑的 $100 \mathrm{~km}$ 海 域范围内, 海水声速剖面变化较大. 假设浅海平坦海域 为典型的浅海负梯度声速剖面, 深海平坦海域声速剖 面为标准的Munk曲线, 声道轴深度为 $1300 \mathrm{~m}$. 陆架斜 坡区域的声速剖面采用 $10 \mathrm{~km}$ 距离分段, 即每隔 $10 \mathrm{~km}$ 变化一次声速剖面, 各距离段的声速剖面由RAM软件 生成. 图2给出了整个传播距离上的声速剖面. 图3给 出了频率为 $190 \mathrm{~Hz}$ 时, 陆架斜坡海域上坡传播声场分

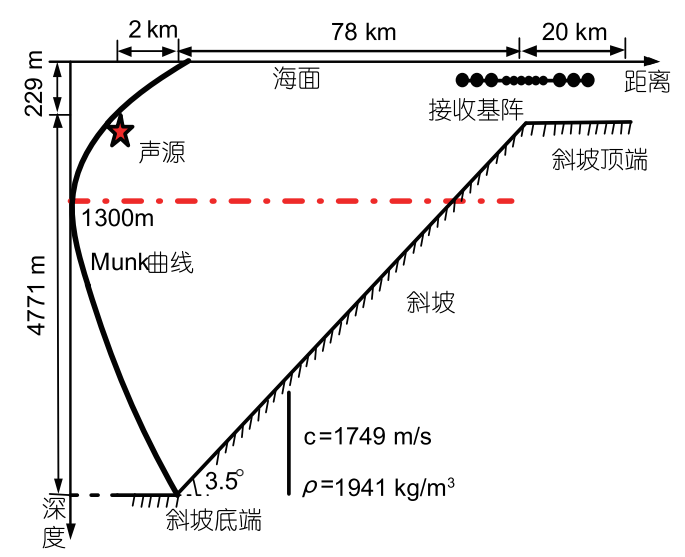

图 1 (网络版彩图)上坡传播仿真环境及参数示意图 Figure 1 (Color online) The sketch of upslope environment and parameters used in simulations.

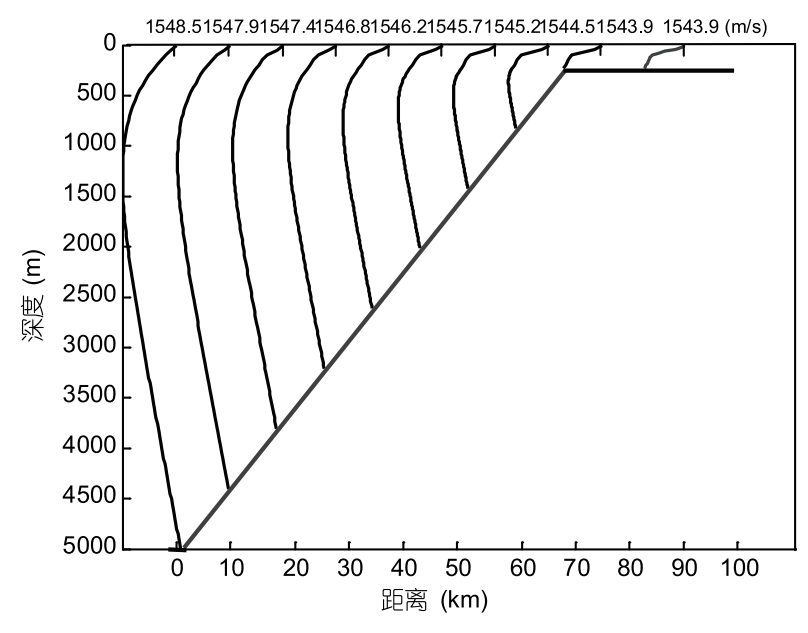

图 2 上坡声传播 $10 \mathrm{~km}$ 距离分段的声速剖面

Figure 2 Sound speed profiles of the upslope acoustic propagation environment at $10 \mathrm{~km}$ interval.

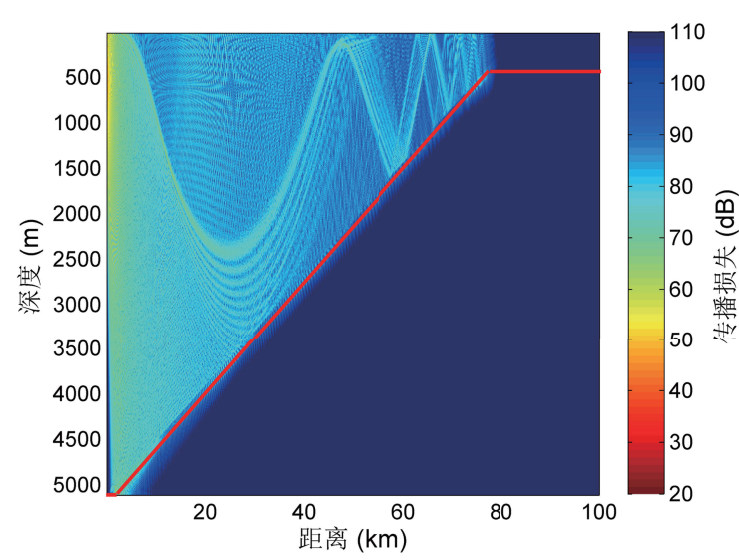

图 3 (网络版彩图)频率 $190 \mathrm{~Hz}$ 时上坡声传播损失分布图 Figure 3 (Color online) Sound field of upslope acoustic propagation at $190 \mathrm{~Hz}$.

布图, 红线标出海底和海水的分界线.

\section{2 声场相关性与信号协方差矩阵特征值分析}

图4给出了 $120 \mathrm{~m}$ 接收深度上距离声源 30 和 $50 \mathrm{~km}$ 处, 不同阵元间的声场水平纵向相关性图. 可以看出, 随着阵元间距的增大, $30 \mathrm{~km}$ 距离上的声场相关长度 较小, 而 $50 \mathrm{~km}$ 距离上各个阵元间均有较强的相关性. 图5给出了 80,120 和 $200 \mathrm{~m}$ 接收深度上距离声源 30 和 50 $\mathrm{km}$ 处, 各阵元与第一个阵元间的声场水平纵向相关性 图. 可以看出, 深度为 $80 \mathrm{~m}$ 时, 30 和 $50 \mathrm{~km}$ 距离上的声场 

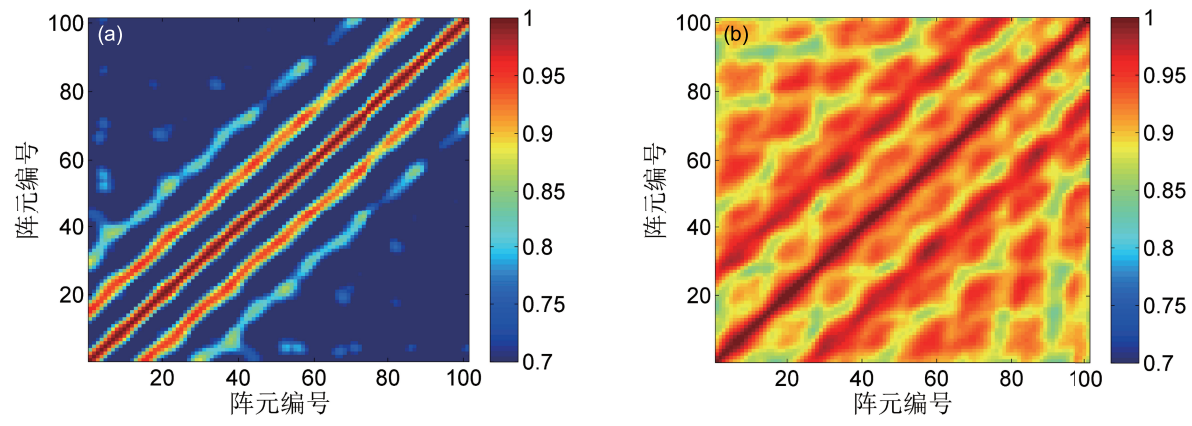

图 4 (网络版彩图)距离声源 $30 \mathrm{~km}$ (a)和 $50 \mathrm{~km}$ (b)时的声场相关性

Figure 4 (Color online) The horizontal longitudinal correlation of the sound field when the range is $30 \mathrm{~km}$ (a) and $50 \mathrm{~km}$ (b), respectively.
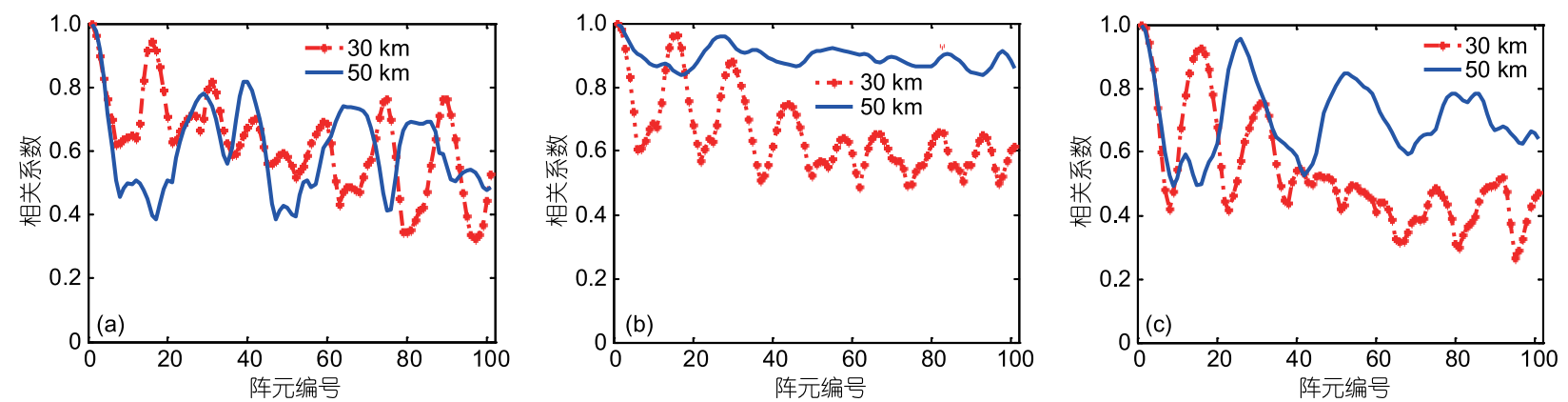

图 5 (网络版彩图)距离声源 30 和 $50 \mathrm{~km}$ 时不同深度处((a) 深度 $80 \mathrm{~m}$; (b) 深度 $120 \mathrm{~m}$; (c) 深度 $200 \mathrm{~m}$ )的声场水下纵向相关性曲线 Figure 5 (Color online) The horizontal longitudinal correlation at different depths ((a) $80 \mathrm{~m}$; (b) $120 \mathrm{~m}$; (c) $200 \mathrm{~m}$ ) when the range is 30 and $50 \mathrm{~km}$, respectively.

相关系数相差较小; 深度为 120 和 $200 \mathrm{~m}$ 时, $50 \mathrm{~km}$ 距离 上的声场相关系数明显大于 $30 \mathrm{~km}$ 距离上的声场相关 系数. 这是因为 $30 \mathrm{~km}$ 距离位于声场影区, 接收声场主 要由海底反射声贡献; 而50 km距离则位于声场会聚 区, 但较浅深度 $($ 如 $80 \mathrm{~m}$ ) 接收时亦处于声影区. 声场 相关系数的大小将影响到常规波束形成器和MVDR 波束形成器的阵增益.

图6给出了距离声源 30 和 $50 \mathrm{~km}$ 时, 不同深度上水 平阵接收信号协方差矩阵的特征值分布图. 可以看出, 深度为 $80 \mathrm{~m}$ 时, $30 \mathrm{~km}$ 距离上接收信号协方差矩阵的 最大特征值较大; 而深度为 120 和 $200 \mathrm{~m}$ 时, $50 \mathrm{~km}$ 距离 上的信号协方差矩阵最大特征值明显大于 $30 \mathrm{~km}$ 距离 上的信号协方差矩阵最大特征值. 特征值的大小将直 接影响到特征值波束形成器的阵增益 ${ }^{[5]}$.

\section{3 三种波束形成器的阵增益}

利用水声传播原理, 分别获得水平阵在陆架斜坡 海域不同深度和不同距离时各阵元接收信号数据. 假
设水平阵接收噪声是高斯白噪声, 由于声源辐射信号 到达各接收阵元时的传播损失不同, 这里使用水平阵 各阵元接收信号功率和噪声功率之比的平均, 代表基 阵接收数据的信噪比, 仿真中水平阵各接收阵元的平 均信噪比为 $-10 \mathrm{~dB}$.

图7给出了接收深度为 $80 \mathrm{~m}$ 时, 距离声源 30 和 50 $\mathrm{km}$ 处三种波束形成器的阵增益随阵元个数变化曲线. 可见, 随着阵元个数的增加, MVDR-BF的阵增益略大 于 $\mathrm{CBF}$, 但两者均小于 $\mathrm{EBF}$ 的阵增益. 随着水平阵阵元 个数的增加, $\mathrm{CBF}$ 和MVDR-BF阵增益出现下降的趋 势. 结合图5(a)进行分析可得, 当接收深度为 $80 \mathrm{~m}$ 时, 随着阵元个数的增加, 距离声源 30 和 $50 \mathrm{~km}$ 的声场相 关系数严重下降, 致使CBF和MVDR-BF的阵增益随着 阵元个数的增加呈现下降的趋势. EBF的阵增益不随 阵元个数的增加而减小, 且水平阵距离声源 $30 \mathrm{~km}$ 时 $\mathrm{EBF}$ 的阵增益大于其距离声源 $50 \mathrm{~km}$ 时的阵增益. 图 中同时给出了阵增益的理论极限 $10 \log N$.

图 8 给出了接收深度为 $120 \mathrm{~m}$ 时, 距离声源 30 和 50 

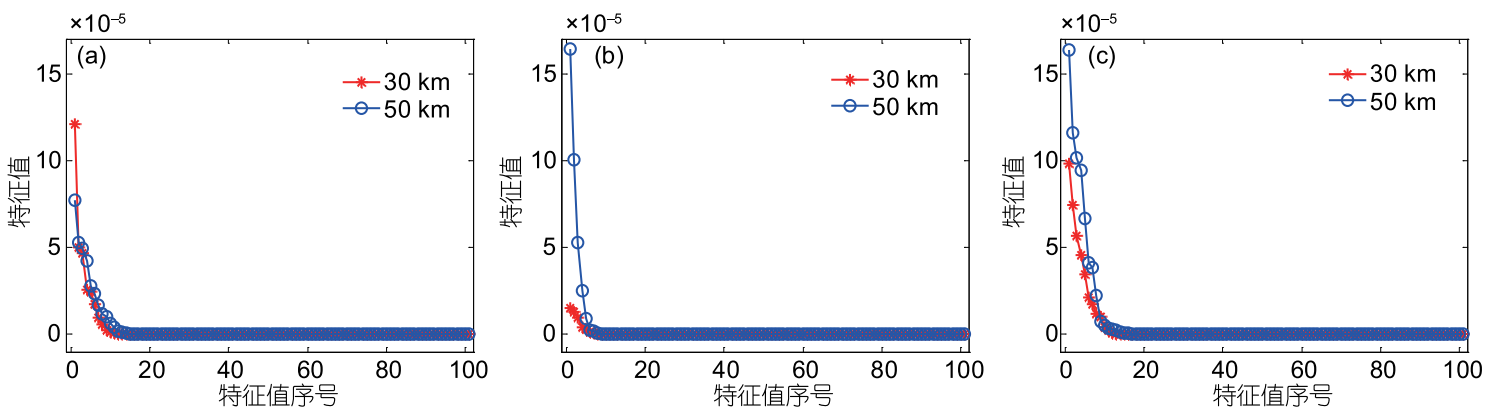

图 6 (网络版彩图)不同深度处((a) 深度 $80 \mathrm{~m}$; (b) 深度 $120 \mathrm{~m}$; (c) 深度 $200 \mathrm{~m}$ )距离声源 30 和 $50 \mathrm{~km}$ 的信号协方差矩阵特征值 分布曲线

Figure 6 (Color online) The eigenvalues of the signal covariance matrix at different depths ((a) $80 \mathrm{~m}$; (b) $120 \mathrm{~m}$; (c) $200 \mathrm{~m}$ ) when the range is 30 and $50 \mathrm{~km}$, respectively.
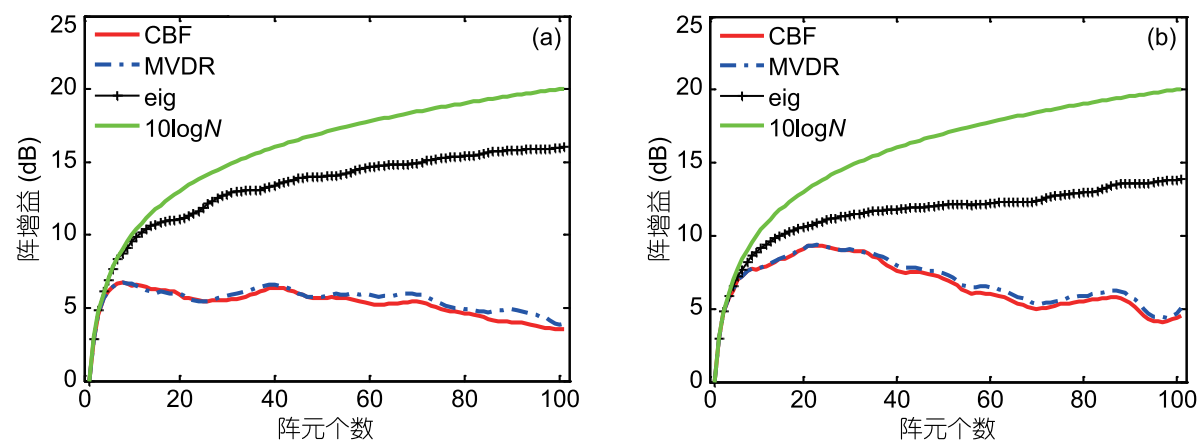

图 7 (网络版彩图)接收深度为 $80 \mathrm{~m}$ 时, 距离声源 $30 \mathrm{~km}$ (a)和 $50 \mathrm{~km}(\mathrm{~b})$ 三种波束形成器的阵增益随阵元个数变化曲线

Figure 7 (Color online) Array gains of different beamformers varying with distance, when the horizontal ULA is $30 \mathrm{~km}$ (a) and $50 \mathrm{~km}$ (b) away from the source, respectively, and the receiver depth is $80 \mathrm{~m}$.
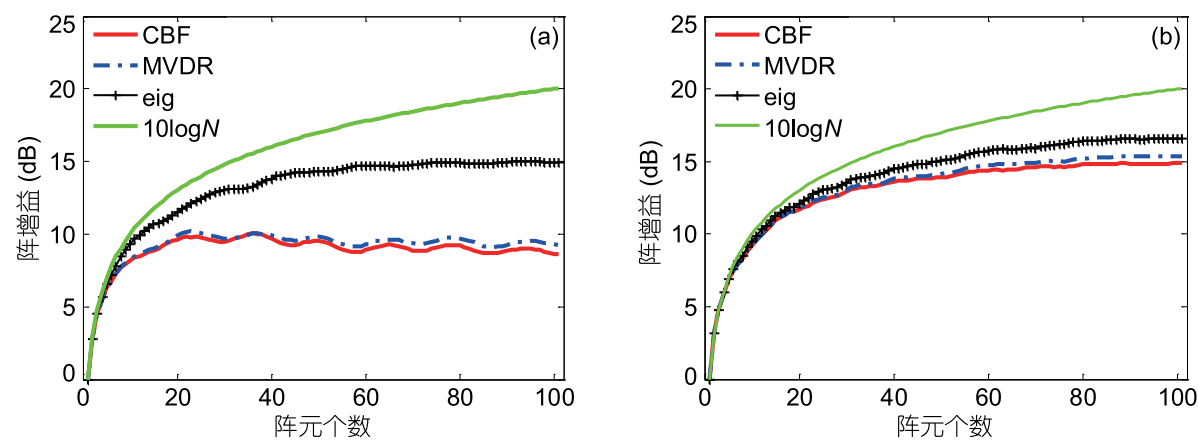

图 8 (网络版彩图)接收深度为 $120 \mathrm{~m}$ 时, 距离声源 $30 \mathrm{~km}$ (a)和 $50 \mathrm{~km}$ (b) 三种波束形成器的阵增益随阵元个数变化曲线 Figure 8 (Color online) Array gains of different beamformers varying with distance, when the horizontal ULA is $30 \mathrm{~km}$ (a) and $50 \mathrm{~km}$ (b) away from the source, respectively, and the receiver depth is $120 \mathrm{~m}$.

$\mathrm{km}$ 处三种波束形成器的阵增益随阵元个数变化曲线. 可见, MVDR-BF的阵增益略大于 $\mathrm{CBF}$, 但两者均小于 $\mathrm{EBF}$ 的阵增益. 水平阵距离声源 $30 \mathrm{~km}$ 时, 当阵元个数
超过26个时, CBF和MVDR-BF的阵增益不再随着阵元 个数的增加而增大; 而距离声源 $50 \mathrm{~km}$ 时, 当阵元个数 超过 87 个时, $\mathrm{CBF}$ 和MVDR-BF的阵增益不再随着阵元 

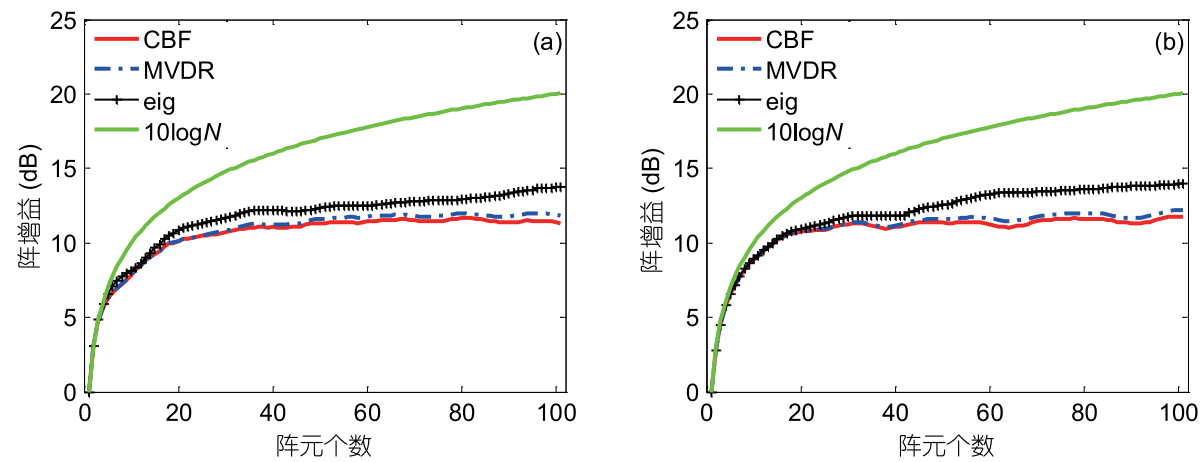

图 9 (网络版彩图)接收深度为 $200 \mathrm{~m}$ 时, 距离声源 $30 \mathrm{~km}(\mathrm{a})$ 和 $50 \mathrm{~km}(\mathrm{~b})$ 三种波束形成器的阵增益随阵元个数变化曲线 Figure 9 (Color online) Array gains of different beamformers varying with distance, when the horizontal ULA is $30 \mathrm{~km}$ (a) and $50 \mathrm{~km}$ (b) away from the source, respectively, and the receiver depth is $200 \mathrm{~m}$.

个数的增加而增大. 结合图5(b)分析可得, 两接收位置 点的阵增益随阵元个数变化曲线不同, 是由于随着阵 元个数的增加, 距离声源 $30 \mathrm{~km}$ 的声场相关系数下降较 严重, 而距离声源 $50 \mathrm{~km}$ 的声场相关系数一直保持较 大的值. 水平阵距离声源 30 和 $50 \mathrm{~km}$ 时, $\mathrm{EBF}$ 的阵增益 均随着阵元个数的增加而增大, 且水平阵距离声源 50 $\mathrm{km}$ 时 $\mathrm{EBF}$ 的阵增益大于其距离声源 $30 \mathrm{~km}$ 时的阵增益.

图9给出了接收深度为 $200 \mathrm{~m}$ 时, 距离声源 30 和 50 $\mathrm{km}$ 处三种波束形成器的阵增益随阵元个数变化曲线. 可见, MVDR-BF的阵增益略大于 $\mathrm{CBF}$, 当阵元个数大 于 34 个时, 随着阵元个数的增加, CBF和MVDR-BF的 阵增益不再增大而趋于稳定. 可见, 由于声场相关性 的下降导致这两种波束形成器的阵增益不会随着阵元 个数的增加而一直增大. 水平阵距离声源 30 和 $50 \mathrm{~km}$ 时, $\mathrm{EBF}$ 的阵增益均随着阵元个数的增加而增大, 且大 于 $\mathrm{CBF}$ 和MVDR-BF的阵增益. 水平阵距离声源 $50 \mathrm{~km}$ 时 $\mathrm{EBF}$ 的阵增益略大于其距离声源 $30 \mathrm{~km}$ 时的阵增益.

由以上分析可见, 当接收数据信噪比为 $-10 \mathrm{~dB}$ 时, MVDR-BF的阵增益略大于 CBF. CBF 和MVDR-BF 的 阵增益与声场相关性有关: 当声场相关系数一直保持 较大值时, 两种波束形成器的阵增益随着阵元个数的 增加而增加, 而当阵元个数增大到一定值时(如图8(a), 阵元个数超过 87 个时), 阵增益将不再增加; 当声场相 关系数随着阵元个数的增加下降较严重时, 阵元个数 超过 26 个(图 8(b)) 和34个(图9)时, CBF和MVDR-BF的 阵增益均不再随着阵元个数的增加而增大.

$\mathrm{EBF}$ 的阵增益受声场相关性下降的影响较小, 且大 于 $\mathrm{CBF}$ 和MVDR-BF的阵增益. $\mathrm{EBF}$ 的阵增益与水平阵
接收信号协方差矩阵的最大特征值有关: 如图 8 , 水平 阵距离声源 $30 \mathrm{~km}$ 的接收信号协方差矩阵最大特征值 大于其在 $50 \mathrm{~km}$ 的信号协方差矩阵最大特征值(图6(a)), 导致距离 $30 \mathrm{~km}$ 时的EBF阵增益较大; 再如图 8 和 9 , 水平 阵距离声源 $50 \mathrm{~km}$ 的接收信号协方差矩阵最大特征值 大于其在 $30 \mathrm{~km}$ 的信号协方差矩阵最大特征值(图6(b) 和图6(c)), 导致距离 $50 \mathrm{~km}$ 时的EBF阵增益较大. 可见, $\mathrm{EBF}$ 的阵增益基本受声场相关性的影响较小, 其大小 由信号协方差矩阵最大特征值与其所有特征值之和 的比值决定, 该比值越大时, EBF的阵增益越高.

\section{3 结论}

本文针对陆架斜坡海域上坡波导环境, 对 $\mathrm{CBF}$, MVDR-BF和EBF三种波束形成器的阵增益进行了仿 真研究, 结果表明:

(1) 当接收数据的信噪比为 $-10 \mathrm{~dB}$ 时, MVDR的阵 增益略高于 $\mathrm{CBF}$, 但都小于 $\mathrm{EBF}$ 的阵增益.

(2) CBF和MVDR的阵增益与声场相关性有关, 当 声场相关系数一直保持较大值时, 两种波束形成器的 阵增益随着阵元个数的增加而增加, 而当阵元个数增 大到一定值时, 阵增益将不再增加; 当声场相关系数 随着阵元个数的增加下降较严重时, 阵元个数超过一 定的值后, $\mathrm{CBF}$ 和MVDR-BF的阵增益均不再随着阵元 个数的增加而增大.

(3) EBF的阵增益受声场相关性的影响较小, 阵增 益的大小与信号协方差矩阵的最大特征值有关, 当最 大特征值与所有特征值的比值越大时, 阵增益越高. 


\title{
参考文献
}

1 Urick R J. Principles of Underwater Sound for Engineers. New York: McGraw-Hill, 1967

2 Cox H. Line array performance when the signal coherence is spatially dependent. J Acoust Soc Am, 1973, 54: 1743-1746

3 Green M C. Gain of a linear array for spatially dependent signal coherence. J Acoust Soc Am, 1976, 60: 129

4 Hamson R M. The theoretical gain limitations of a passive vertical line array in shallow water. J Acoust Soc Am, 1980, 68: 156-164

5 Morgan D R. Coherence effects on the detection performance of quadratic array processors, with applications to large-array matched-field beamforming. J Acoust Soc Am, 1990, 87: 737

6 Yoo K, Yang T C. Improved vertical array performance in shallow water with a directional noise field. J Acoust Soc Am, 1998, 104: 3326-3338

7 Liu Q Y, Song J, Zhao C M. Directional analysis of horizontal long line array in shallow water multipath channel (in Chinese). Acoust Electron Eng, 2010, 2: 8-10 [刘清宇, 宋俊, 赵春梅. 水平长线阵在浅海多途信道中的指向性分析. 声学与电子工程, 2010, 2: 8-10]

8 Song J. Underwater Acoustical Problems of Large-Aperture Line Fiber Optic Hydrophone Array (in Chinese). Diseertation for Doctoral Degree. Changsha: National University of Defense Technology, 2005 [宋俊. 光纤水听器长线阵应用的水声物理问题. 博士学位论文. 长沙: 国防 科技大学, 2005]

9 Yu H. The performance of sonar affected by spatial-temporal characteristics and attenuation of sound field in shallow water (in Chinese). Ship S\&T, 1991, 6: 1-8 [于瀚. 浅海声场时空相关性及其衰减对声纳性能的影响. 舰船科学技术, 1991, 6: 1-8]

10 Collins M D. A split-step Padé solution for the parabolic equation method. J Acoust Soc Am, 1993, 93: 1736-1742

11 Su X X, Zhang R H, Li F H. Improvement of the longitudinal correlations of acoustical field by using the waveguide invariance (in Chinese). Acta Acust, 2006, 4: 305-309 [苏晓星, 张仁和, 李风华. 利用波导不变量提高声场的水平纵向相关. 声学学报, 2006, 4: 305-309]

12 Capon J. High-resolution frequency-wavenumber spectrum analysis. Proc IEEE, 1969, 57: 1408-1418

\section{Array gain of a horizontal uniform linear array in the continental shelf slope}

\author{
XIE Lei \& SUN Chao* \\ School of Marine Science and Technology, Northwestern Polytechnical University, Xi'an 710072, China
}

The acoustic environment of the continental shelf slope waveguide is very complex. For an underwater acoustic array in this area, the amplitude and phase of the received signals will be distortional, which leads to the signal correlation attenuation and the array gain of the beamformer decreasing. However, there has been little work on the array gains of different beamformers in the acoustic propagation environment of the continental shelf slope. In this paper, a horizontal uniform linear array (ULA) receiving signals from a shallow source is considered in the upslope propagation condition and the array gains of conventional beamformer (CBF), minimum variance distortionless response (MVDR-BF) and eigenvalue beamformer (EBF) are presented. The results of numerical simulations show that: 1) the array gain of CBF and MVDR-BF is related to the horizontal longitudinal correlation of the sound field and will not increase anymore when the number of the hydrophone exceeds a certain value. 2) The array gain of EBF is determined by the ratio of the maximum eigenvalue to the sum of all eigenvalues of the signal covariance matrix. 3) The array gain of MVDR-BF is larger than that of $\mathrm{CBF}$ when the signal-to-noise ratio of the receive data is $-10 \mathrm{~dB}$, but both of them are smaller than the array gain of EBF.

continental shelf slope, array gain, beamformer, horizontal longitudinal correlation

PACS: $43.30 .+\mathrm{m}, 43.60 .+\mathrm{d}, 43.60 . \mathrm{Fg}$

doi: $10.1360 /$ SSPMA2016-00123 